\title{
Water Absorption and Dimensional Stability of Heat-treated Fast-growing Hardwoods ${ }^{1}$
}

\author{
Trisna PRIADI $\mathbb{D}^{2, \dagger} \cdot$ Maratus SHOLIHAH ${ }^{2} \cdot$ Lina KARLINASARI ${ }^{2}$
}

\begin{abstract}
A common problem with fast-growing hardwoods is dimensional instability that limits use of their wood. In this study, we investigated the effects of pre-drying methods, temperatures, and heating duration on the specific gravity, water absorption, and dimensional stability of three tropical fast-growing hardwoods, jabon (Neolamarckia cadamba Roxb.), sengon (Falcataria moluccana Miq.), and mangium (Acacia mangium Willd.). Wood samples were pre-dried by two methods (fan and oven at $40{ }^{\circ} \mathrm{C}$ ), and heat treatments were performed at three temperatures $(120$, 150, and $180{ }^{\circ} \mathrm{C}$ ) for two different time periods ( 2 and 6 hours). The specific gravity, water absorption, dimensional stability, and structural changes of the samples were evaluated. The results revealed that heat treatments slightly reduced the specific gravity of all three wood species. In addition, the heat treatments reduced water absorption and significantly improved dimensional stability of the samples. Oven pre-drying followed by heat treatment at $180{ }^{\circ} \mathrm{C}$ for 6 hours resulted in good physical improvement of jabon and sengon wood. Fan pre-drying followed by heat treatment at $180{ }^{\circ} \mathrm{C}$ for 2 hours improved the physical properties of mangium wood. The heat treatment shows a promising technique for improving the physical characteristic of fast growing hardwoods.
\end{abstract}

Keywords: microcheck, physical properties, swelling, wood modification, wood ultrastructure

\section{INTRODUCTION}

Dimensional stability and moisture content are important physical properties of wood that influence the range of applications for wood products. The hygroscopic nature of wood causes variation in the moisture content, which in turn causes dimensional instability. Efforts to solve this problem have strongly relied on chemical treatments. Chemical modification of wood protects it against water, decay, ultraviolet and thermal degradation. Dimensional stability can be greatly improved by simple reactions with acetic anhydride (Rowell, 2006). Other studies have been performed to explore acetylation of the wood (Nagarajappa and Pandey, 2016; Huang et al., 2018) and impregnation of wood with substances such as rosin and paraffin (Esteves et al., 2014; Dong et al., 2016). However, due to growing awareness of environmental issues, consumers want durable wood products, but they also want to avoid negative risks of using chemicals. Therefore physical treatment such as heating for wood quality improvement is a very prospective method and

\footnotetext{
${ }^{1}$ Date Received January 10, 2019, Date Accepted August 10, 2019

2 Department of Forest Products, IPB University, Bogor 16680, Indonesia

$\dagger$ Corresponding author: Trisna PRIADI (e-mail: trisnapriadi@yahoo.com, ORCID: 0000-0003-0776-7776)
} 
needs to be developed.

Heat treatment is a physical treatment method that effectively improves the dimensional stability and other properties of wood. During heat treatment, wood is heated to more than $100{ }^{\circ} \mathrm{C}$ for varying lengths of time, from 15 minutes to 24 hours. The specific conditions depend on the heat treatment process, wood type, wood dimension, and moisture content, as well as the desired mechanical properties, resistance to biological attack, and dimensional stability of the final product (Kamdem et al., 2002). Various methods of wood heat treatment have been investigated, such as hydrothermal processing and steam injection, (Esteves et al., 2008). The effects of super heated steam method of heat treatment on wood properties have been explored by Park et al. (2016, 2018). On the other hand, Won et al. (2017) used sulfuric acid (7.5\%) immersion as a catalyst before heat treatment at $130{ }^{\circ} \mathrm{C}$ for 90 minutes that improved the decay resistance of Korean red pine (Pinus densiflora) and Japanese larch (Larix kaempferi) woods from brown rot fungus (Fomitopsis palustris).

Heat treatment changed wood structure, particularly in tracheid walls and ray tissue (Awoyemi and Jones, 2011). Heat treatment at $190{ }^{\circ} \mathrm{C}$ for 3 hours increased the sound absorption rate and permeability of malas wood (Homalium foetidum) (Kang et al., 2018). The physical and chemical properties of wood change during the heating process (Windeisen et al., 2007). Heat treatment of wood improve resistance to fungi (Hao et al., 2018); reduce water content and surface wettability of wood (Esteves et al., 2007); cause wood to become darker and increase its dimensional stability (Korkut et al., 2008; Priadi and Hiziroglu, 2013). Lim et al. (2014) reported that heat treatment at $170{ }^{\circ} \mathrm{C}$ and $190{ }^{\circ} \mathrm{C}$ significantly improved dimensional stability of Korean pine (Pinus koraiensis). Heat treatment at $180{ }^{\circ} \mathrm{C}$ reduced surface roughness of various fastgrowing tropical hardwoods (Karlinasari et al., 2018). In addition, consumers prefer the darker colors of heated wood over the brighter colors of unprocessed wood (Hidayat et al., 2017).

There are some disadvantage of heat treatment that should be minimized. The hardness and modulus of rupture of wood are reduced with heating at $175{ }^{\circ} \mathrm{C}$ and $200{ }^{\circ} \mathrm{C}$ (Won et al., 2012). Research on heat treatment mainly focuses on softwoods and temperate woods, and relatively little is known regarding the application of high temperature heating for fast-growing hardwoods. Intensive study is needed to resolve this limitation.

Fast-growing wood species, mainly sengon (Falcataria moluccanaMiq.), mangium (Acacia mangium Willd.), and jabon (Neolamarckia cadamba Roxb.), are increasingly grown in plantation and community forests in Indonesia. Compared to the other species, mangium had the highest log productionin 2015, reaching approximately 22.91 million $\mathrm{m}^{3}$, or $52.22 \%$ of Indonesia's total log production. Mangium log production primarily occurred on four major islands, Sumatra, Java, Kalimantan, and Sulawesi. Sengon log production was the highest on Java, accounting for 2.51 million $\mathrm{m}^{3}$, or $50.84 \%$ of the total log production on Java. Sengon wood was produced on almost all islands in Indonesia (BPS-Statistics Indonesia, 2015). Jabon is a commodity with very good prospects, owing in large part to its rapid growth; within 5 years, the tree diameter can reach $30-40 \mathrm{~cm}$ and has good economic value (Mansur and Tuheteru, 2010). Jabon logs are produced on Sumatera, Java, Sulawesi, and Maluku islands (BPS-Statistics Indonesia, 2015).

Fast-growing wood species are commonly grown in short rotation plantation forests that are less than 10 years old. The productivity of fast-growing hardwoods is high, but the wood has several problems, particularly in regard to the physical-mechanical properties and durability. Bao et al. (2001) reported that short rotation trees have higher juvenile wood content, which generally leads to inferior physico-mechanical properties 
in comparison with the properties of wood from mature trees.

Generally, sengon wood has a specific gravity (SG) of 0.33 (Martawijaya et al., 2005), while the SG of mangium and jabon woods is $0.4-0.45$ and $0.29-0.56$, respectively (Krisnawati et al., 2011a, 2011b). Techniques are needed to improve the SG and thus the quality of these three fast-growing hardwoods species. The objective of this research is to investigate the effect of heat treatment on water absorption and the dimensional stability of fast-growing hardwoods, specifically, jabon, sengon, and mangium, which hold great promise for community and plantation forest development.

\section{MATERIALS and METHODS}

This research was conducted at the Workshop and the Physical Properties Laboratory of the Wood Division of Wood Quality Improvement, Forest Products Department, Bogor Agricultural University and BATAN (National Nuclear Energy Agency of Indonesia). Jabon, sengon, and mangium trees, 8-10 years old, were harvested in Dramaga, Bogor, West Java Province, Indonesia. The logs were sawn into $3 \mathrm{~cm}(\mathrm{R}) \times 20 \mathrm{~cm}$ (T) $\times 130 \mathrm{~cm}(\mathrm{~L})$ boards.

\subsection{Sample preparation}

Jabon, sengon, and mangium boards were cut into various sample sizes. The SG test used $2 \mathrm{~cm}(\mathrm{R}) \times$ $2 \mathrm{~cm}(\mathrm{~T}) \times 2 \mathrm{~cm}(\mathrm{~L})$ samples, and the water absorption and dimensional stability tests used $2 \mathrm{~cm}(\mathrm{R}) \times 2 \mathrm{~cm}$ $(\mathrm{T}) \times 8 \mathrm{~cm}(\mathrm{~L})$ samples. The wood structure analysis used $1 \mathrm{~cm}(\mathrm{R}) \times 1 \mathrm{~cm}(\mathrm{~T}) \times 2 \mathrm{~cm}(\mathrm{~L})$ samples, and $0.5 \mathrm{~cm}(\mathrm{R}) \times 0.5 \mathrm{~cm}(\mathrm{~T}) \times 0.5 \mathrm{~cm}(\mathrm{~L})$ samples were used for ultrastructure observation using scanning electron microscope (SEM). Each test had four replications. All samples were stored at room temperature and prepared for pre-dried and heat treatment process.

\subsection{Pre-drying and heat treatments}

Pre-drying was done to reduce moisture content of wood and prevent checking during heat treatment. The average moisture content of wood samples before pre-drying was $25 \%$. Samples were pre-dried by fan pre-drying or oven pre-drying. Fan pre-drying used a Sekai IFL 1850 high velocity tornado fan (100 W, 45-cm diameter, maximum speed on a scale of 3 ). Fan predrying was conducted at room temperature $\left( \pm 27^{\circ} \mathrm{C}\right)$ for 21 days to attain a wood moisture content of $15 \%$ to $18 \%$, while oven pre-drying was done at $40{ }^{\circ} \mathrm{C}$ for 7 days to attain a wood moisture content of $8 \%$ to $10 \%$. Subsequent heat treatment was applied in an experimental kiln at temperatures of $120^{\circ} \mathrm{C}, 150{ }^{\circ} \mathrm{C}$, and $180{ }^{\circ} \mathrm{C}$ under atmospheric pressure without humidity control. Air circulation in the kiln was forced with a $2 \mathrm{hp}$ fan $(1.5 \mathrm{kWh})$. The heating periods were 2 and 6 hours. The kiln took 4,6 and 8 hours to reach temperature 120,150 , and $180{ }^{\circ} \mathrm{C}$ respectively.

\subsection{Physical properties tests}

The SG samples were soaked in water under air pressure at 6 atm for 4 hours, followed by volume measurement. The samples were then dried at $103 \pm$ $2{ }^{\circ} \mathrm{C}$ until reaching a constant weight to determine the oven dry weight. The SG was calculated using Equation (1).

$$
\mathrm{SG}=(\mathrm{ODW} / \mathrm{WV}) / \rho
$$

where, $\mathrm{SG}=$ specific gravity, ODW $=$ oven dry weight (g), WV = wet volume $\left(\mathrm{cm}^{3}\right), \rho=$ water density $(1$ $\left.\mathrm{g} / \mathrm{cm}^{3}\right)$.

In a previous study (Priadi and Hiziroglu, 2013), samples were soaked in water for 2 hours for the wood dimensional stability test. In the current research, to be more convincing, a longer water soaking period, 8 hours, was used for the water absorption and 
dimensional stability tests. The weight and dimensions (in tangential, radial, and longitudinal directions) of the samples were measured before and after water soaking. The samples were then dried at $103 \pm 2{ }^{\circ} \mathrm{C}$ until reaching a constant weight to obtain the oven dry weight. The moisture content and water absorption were calculated used Equations (2) and (3).

$$
\begin{aligned}
\mathrm{MC} & =(\mathrm{MW}-\mathrm{ODW}) / \mathrm{ODW} \times 100 \\
\mathrm{~A} & =(\mathrm{W} 2-\mathrm{W} 1) / \mathrm{ODW} \times 100
\end{aligned}
$$

where, $\mathrm{MC}=$ moisture content $(\%), \mathrm{MW}=$ weight at determination (g), ODW = oven dry weight $(\mathrm{g}), \mathrm{A}=$ water absorption (\%), W1 = weight before soaking (g), $\mathrm{W} 2$ = weight after soaking (g).

The dimensional stability was evaluated based on anti-swelling efficiency (ASE) value that used Equation (4) and (5).

$$
\begin{array}{r}
\mathrm{SW}=(\mathrm{D} 2-\mathrm{D} 1) / \mathrm{D} 1 \times 100 \\
\mathrm{ASE}=(\mathrm{SWc}-\mathrm{SWt}) / \mathrm{SWc} \times 100
\end{array}
$$

where, SW = swelling (\%), D1 = dimension before soaking $(\mathrm{cm}), \mathrm{D} 2$ = dimension after soaking $(\mathrm{cm})$, ASE = anti swelling efficiency (\%), SWc = swelling of control sample (\%), SWt $=$ swelling of treated sample (\%).

\subsection{Wood structure analysis}

Wood structure analysis was performed to evaluate defects arising from the process of heating. The scanning electron microscope JEOL JSM-6510LA was used for ultramicroscopic observation of wood sample without coating.

\subsection{Data analyses}

The effects of heat treatment on SG, water absorption, and dimensional stability of the wood samples were analyzed statistically using a factorial completely randomized design with three factors. Factor A was the pre-drying method (fan or oven), factor $\mathrm{B}$ was the heat treatment temperature $\left(120^{\circ} \mathrm{C}, 150{ }^{\circ} \mathrm{C}\right.$, or $\left.180^{\circ} \mathrm{C}\right)$, and factor $\mathrm{C}$ was the heating time $(0,2$, or 6 hours). If the analysis of variance (ANOVA) revealed a significant influence at a 95\% confidence interval, Duncan's test was carried out. Data processing used Microsoft Excel 2010 and SPSS 17.0.

\section{RESULTS and DISCUSSION}

\subsection{Specific gravity}

We found that the SG of jabon, sengon, and mangium wood samples generally decreased with heat treatment (Fig. 1). The SG decreases of jabon, sengon, and mangium were up to $15.74 \%, 10.36 \%$, and $12.06 \%$, respectively. The change in the SG of sengon wood was not statistically significant (Table 1), but the SG of jabon and mangium woods were significantly affected by heating time. Heating for 6 hours resulted in samples having a significantly lower SG than the control sample. The SG of wood samples did not affected by pre-drying method in this heat treatment. We observed an interaction effect between the pre-drying method and heating temperature for the SG of jabon. The lowest SG of jabon wood was associated with oven pre-drying and heating at $180^{\circ} \mathrm{C}$. The specific gravity of the three wood samples heated for 6 hours at $150{ }^{\circ} \mathrm{C}$ was not significantly different from that heated for 2 hours and control samples.

The decrease in SG of the jabon and mangium wood samples after 6 hours of heating at $120{ }^{\circ} \mathrm{C}$ and 150 ${ }^{\circ} \mathrm{C}$ could be associate with release of extractives from the wood. Vybohova et al. (2018) previously found that the amount of extractives in ash wood (Fraxinus excelsior L.) decreased after heat treatment at $160{ }^{\circ} \mathrm{C}$ due to the removal of volatiles. Todaro et al. (2013) also reported that heating at $120{ }^{\circ} \mathrm{C}$ and $180{ }^{\circ} \mathrm{C}$ changed 


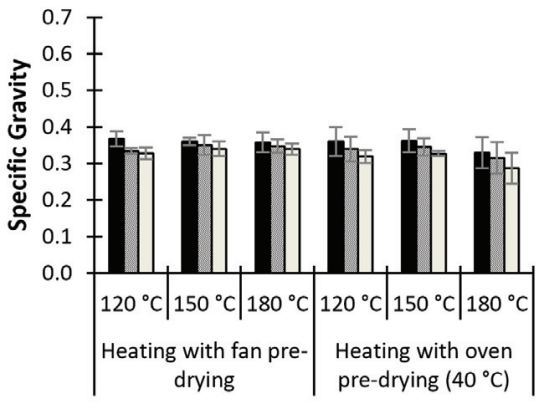

(A)

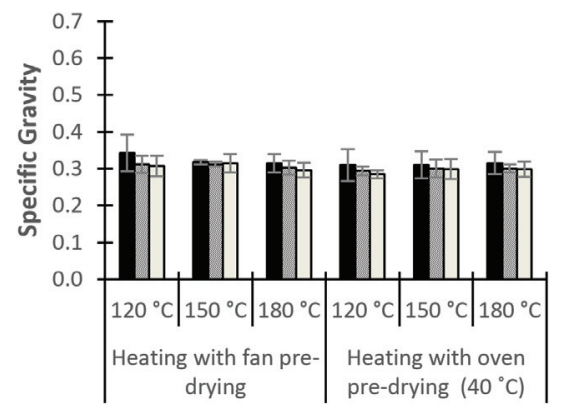

(B)

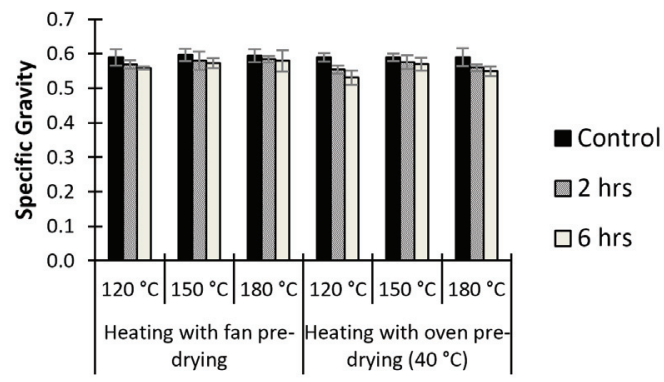

(C)

Fig. 1. Specific gravity of heat-modified jabon (A), sengon (B), and mangium (C) wood.

Table 1. Two-way ANOVA on the effects of pre-drying method, temperature, and heating duration on specific gravity of mangium, sengon, and jabon wood at 95\% confidence level

\begin{tabular}{|c|c|c|c|c|c|c|}
\hline \multicolumn{7}{|c|}{ Specific gravity } \\
\hline & \multicolumn{2}{|c|}{ Jabon } & \multicolumn{2}{|c|}{ Sengon } & \multicolumn{2}{|c|}{ Mangium } \\
\hline & $\mathrm{F}$ & P-value & $\mathrm{F}$ & P-value & $\mathrm{F}$ & P-value \\
\hline Pre-drying & 3.123 & 0.083 ns & 3.688 & $0.060 \mathrm{~ns}$ & 3.389 & $0.071 \mathrm{~ns}$ \\
\hline Temperature & 2.900 & $0.064 \mathrm{~ns}$ & 0.135 & $0.874 \mathrm{~ns}$ & 1.123 & $0.333 \mathrm{~ns}$ \\
\hline Time & 8.985 & $0.000 * *$ & 1.968 & $0.150 \mathrm{~ns}$ & 7.325 & $0.002 *$ \\
\hline Pre-drying $\times$ temperature & 4.382 & $0.017^{*}$ & 1.340 & $0.270 \mathrm{~ns}$ & 0.167 & $0.847 \mathrm{~ns}$ \\
\hline Temperature $\times$ time & 0.846 & 0.502 ns & 0.592 & $0.670 \mathrm{~ns}$ & 1.527 & $0.207 \mathrm{~ns}$ \\
\hline Pre-drying $\times$ time & 1.562 & $0.219 \mathrm{~ns}$ & 0.146 & $0.865 \mathrm{~ns}$ & 0.145 & $0.866 \mathrm{~ns}$ \\
\hline Pre-drying $\times$ temperature $\times$ time & 0.055 & $0.994 \mathrm{~ns}$ & 0.064 & $0.992 \mathrm{~ns}$ & 2.110 & $0.092 \mathrm{~ns}$ \\
\hline
\end{tabular}

*significant effect $(\mathrm{P}<0.05)$; **very significant effect $(\mathrm{P}<0.01)$; ns, not significant effect.

the extractive content of Turkey oak (Quercus cerris L).

Heating at $180{ }^{\circ} \mathrm{C}$ could affect some hemicellulose components in wood. According to Kačíková et al. (2013), hemicellulose degradation of Norway spruce was detected at a heating temperature of $158{ }^{\circ} \mathrm{C}$. Gokhan and Denis (2009) also reported that high temperature heating caused degradation of extractives and specific chemical components of cell walls, particularly hemi- 
cellulose. Hemicellulose is more prone to thermal degradation than cellulose (Esteves and Pareira, 2009).

\subsection{Absorption and dimensional stability}

Heat treatment was found to reduce water absorption in jabon, sengon, and mangium wood samples (Fig. 2). Control samples of jabon, sengon and mangium had average water absorption of $43 \%, 40 \%$ and $15 \%$ repectively. After heat treatment water absorption reduced by $34 \%$ in jabon, $30 \%$ in sengon, and $49 \%$ in mangium. The ANOVA results (Table 2) revealed that pre-drying, temperature, and heating time had a significant interactive effect on the water absorption of sengon and jabon wood samples, while the absorption for mangium wood was significantly affected by the interaction of pre-drying and temperature and the interaction of pre-drying and heating time. In general, the effect of heating on decreasing water absorption in wood was more evident after fan pre-drying than after oven predrying, possibly due to the occurrence of microchecks in wood after oven pre-drying. Fan pre-drying followed by heating at $180^{\circ} \mathrm{C}$ for 6 hours produced the lowest water absorption, although the values for sengon wood did not significantly differ from those resulting from 2 hours of heating at the same temperature. In mangium wood, the pre-drying fan and heating at $180{ }^{\circ} \mathrm{C}$ for 6 hours resulted in water absorption that was not significantly different from that obtained by heating at $150{ }^{\circ} \mathrm{C}$ for 2 hours or heating at $120{ }^{\circ} \mathrm{C}$ for 6 hours. Water absorption in the wood samples that were heated at $150{ }^{\circ} \mathrm{C}$ for 6 hours was not significantly different from that were heated for 2 hours.

The decrease of water absorption indicates the reduction of wood hygroscopicity. According to Kocaefe et al. (2008) and Korkut et al. (2008), wood

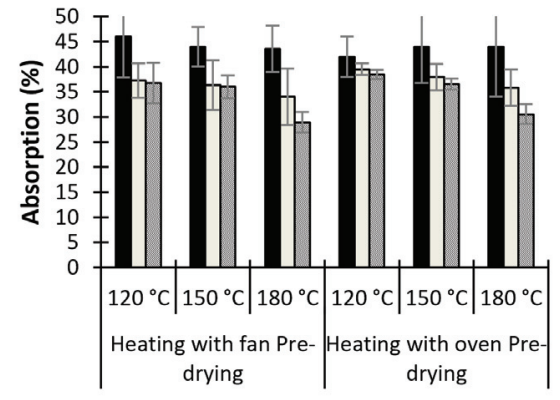

(A)

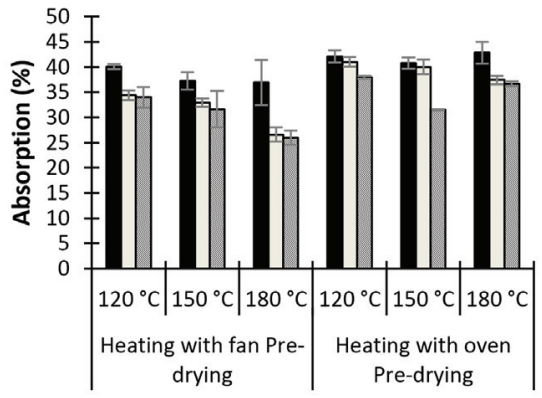

(B)

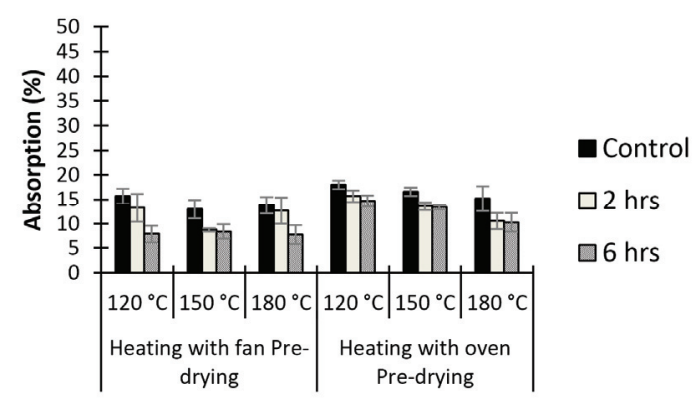

(C)

Fig. 2. Water absorption of heat modified jabon (A), sengon (B), and mangium (C) wood. 
Table 2. Two-way ANOVA on the effects of pre-drying method, temperature, and heating duration on water absorption of mangium, sengon, and jabon wood at $95 \%$ confidence level

\begin{tabular}{lcccccc}
\hline & \multicolumn{7}{c}{ Absorption } & & \\
\hline & \multicolumn{2}{c}{ Jabon } & \multicolumn{2}{c}{ Sengon } & \multicolumn{2}{c}{ Mangium } \\
\cline { 2 - 8 } & $\mathrm{F}$ & P-value & $\mathrm{F}$ & $\mathrm{P}$-value & $\mathrm{F}$ & $\mathrm{P}$-value \\
\hline \hline Pre-drying & 0.358 & $0.552 \mathrm{~ns}$ & 156.998 & $0.000^{* *}$ & 41.765 & $0.000^{* *}$ \\
Temperature & 5.003 & $0.010^{*}$ & 33.413 & $0.000^{* *}$ & 10.730 & $0.000^{* *}$ \\
Time & 19.272 & $0.000^{* *}$ & 58.418 & $0.000^{* *}$ & 39.519 & $0.000^{* *}$ \\
Pre-drying $\times$ temperature & 1.572 & $0.217 \mathrm{~ns}$ & 10.972 & $0.000^{* *}$ & 7.006 & $0.002^{* *}$ \\
Temperature $\times$ time & 3.073 & $0.024^{*}$ & 8.486 & $0.000^{* *}$ & 1.267 & $0.294 \mathrm{~ns}$ \\
Pre-drying $\times$ time & 0.088 & $0.916 \mathrm{~ns}$ & 7.981 & $0.001^{* *}$ & 3.938 & $0.025^{*}$ \\
Pre-drying $\times$ temperature $\times$ time & 3.911 & $0.007^{* *}$ & 3.405 & $0.015^{*}$ & 1.405 & $0.245 \mathrm{~ns}$ \\
\hline
\end{tabular}

*significant effect $(\mathrm{P}<0.05)$; **very significant effect $(\mathrm{P}<0.01)$; ns, not significant.

hygroscopicity decreases due to the reduction of free hydroxyl groups after heat treatment. Xianjun et al. (2011) and Widyorini et al. (2014) also reported that the equilibrium moisture content of wood tends to be lower with increasing temperature and time of heating. Further, Darmawan et al. (2017) suggested that water adsorption of wood is reduced after heating due to the increase of wood crystallinity. Kim et al. (2018) reported that heat treatment at $160{ }^{\circ} \mathrm{C}, 180{ }^{\circ} \mathrm{C}, 200{ }^{\circ} \mathrm{C}$ and $220{ }^{\circ} \mathrm{C}$ for 2 hours increased relative crystallinity of royal paulownia wood, while density decreased slightly with increasing temperature. Further, Kocaefe et al. (2008) reported that reduced water adsorption is associated with the low swelling value of heated wood.

Water absorption in jabon and sengon wood samples was greater than in mangium wood, likely because jabon and sengon have a lower SG compared to mangium. Generally, the lower the wood SG, the higher the water absorption by the wood. The tested SG values of jabon and sengon were 0.36 and 0.32 , while the SG of mangium was 0.59 . Low SG woods generally have higher porosity and permeability than high SG woods.

Wood dimensional stability was evaluated based on ASE. The findings showed that the dimensional stability of the wood samples improved after heat treatment.
The dimensional stability improvement of jabon was better than that of sengon and mangium. The ASE value of jabon wood heated at $180{ }^{\circ} \mathrm{C}$ was $32.85 \%$, while the ASE values of heated sengon and mangium were $16.97 \%$ and $16.29 \%$, respectively (Fig. 3). The higher ASE value of heated wood indicates that the wood swelling was lower than that of the control wood.

Heat treatment with oven pre-drying resulted higher ASE than heat treatment with fan-pre drying in jabon and sengon wood. The ASE value of wood became higher as the heating temperature increased. The ASE values of jabon, sengon, and mangium wood samples that were heated for 6 hours were higher than those of samples heated for 2 hours. Our results were in accordance with those of Hung (2016), who found that the ASE value increased with higher temperatures and heating times. Park et al. (2014) also reported that hot air heating at $180{ }^{\circ} \mathrm{C}$ reduced the equilibrium moisture content and improved the dimensional stability of pitch pine (Pinus rigida) wood. In addition, Lee and Lee (2018) also revealed that heating at temperatures of $120{ }^{\circ} \mathrm{C}, 140{ }^{\circ} \mathrm{C}$, and $160{ }^{\circ} \mathrm{C}$ for $2,6,12$, and 24 hours resulted in the water absorption and thickness swelling of compressed Korean pine decreased with increasing heating temperature and time. 


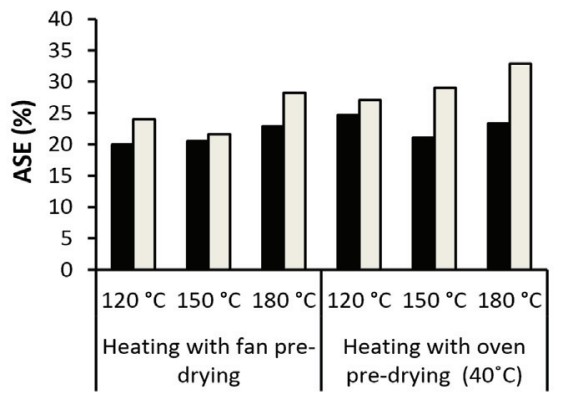

(A)

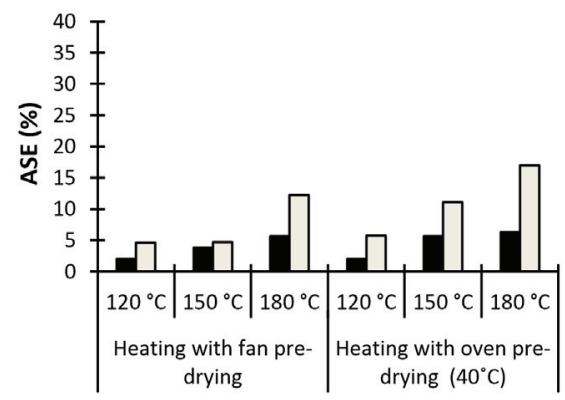

(B)



(C)

Fig. 3. Anti-swelling efficiency (ASE) values of heat modified jabon (A), sengon (B), and mangium $(\mathrm{C})$ woods.

Dimensional stability improvement after heat treatment caused by the reduction of hydroxyl groups and the increase of crystallinity in wood. As reported by Fabiyi and Ogunleye (2015), the number of hydroxyl groups in heat treated obeche (Triplochiton scleroxylon) wood reduced compared to the control samples. The relative cellulose crystallinity increased with increasing temperature and time of heat treatment. Vybohova, et al. (2018) also reported that heating common ash (Fraxinus excelsior L.) wood at temperatures of 160, 180, and $200{ }^{\circ} \mathrm{C}$ for $3,6,9$, and 12 hours caused hemicellulosic monosaccharide (D-xylose) degradation and increased the crystallinity of cellulose.

\subsection{Wood structure analysis}

Based on ultrastructure analysis using SEM, there were some microchecks between cells and in axial parenchyma and rays of jabon and sengon woods that heated at 150 and $180{ }^{\circ} \mathrm{C}$ (Fig. 4). On the other hand, microchecks were already present in mangium when oven pre-drying at $40{ }^{\circ} \mathrm{C}$. In addition, some wood cells collapsed and cell wall checked in mangium wood after heat treatment at 150 and $180{ }^{\circ} \mathrm{C}$. Heat treatment at higher temperatures might cause severe checks in mangium wood. This possibility is in accordance with Inayah (2017), who found checks after heating at $200{ }^{\circ} \mathrm{C}$. According to Basri and Yuniarty (2001), the main problems that arise in the drying of mangium wood are deformation and internal checking. The use of a temperature of $60{ }^{\circ} \mathrm{C}$ at the beginning of drying caused changes in shape, deep rupture, and color degradation in wood. 
Water Absorption and Dimensional Stability of Heat-treated Fast-growing Hardwoods

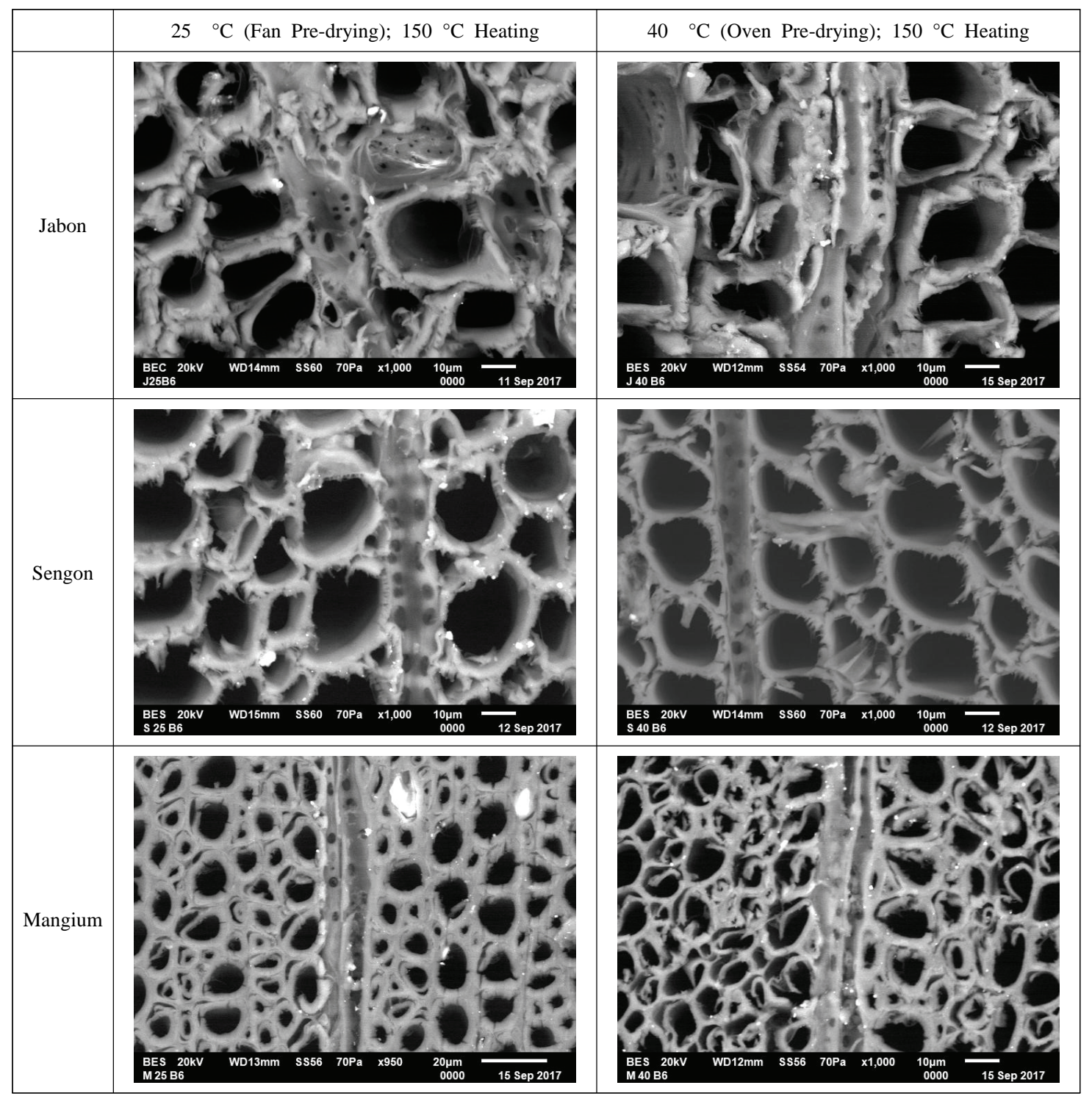

Fig. 4. Cell wall sparation and check in heated jabon, sengon and mangium woods.

\section{CONCLUSION}

Shortcomings in the physical properties of fastgrowing hardwoods such as jabon, sengon, and mangium can be improved by heat treatment. Although the SG of wood was slightly decreased after heat treatment, water absorption was decreased after heat treatment for all three wood species. Furthermore, dimensional stability, as assessed by ASE values, increased with increasing temperature and duration of heating. Oven pre-drying followed by heating at $180{ }^{\circ} \mathrm{C}$ for 6 hours improved the physical properties of jabon and sengon wood, while 
fan pre-drying followed by heat treatment at $180{ }^{\circ} \mathrm{C}$ for 2 hours improved the physical properties of mangium wood.

\section{ACKNOWLEDGMENT}

This research was funded by Directorate for Research and Community Service of the Ministry of Research, Technology and Higher Education (RISTE KDIKTI), Republic of Indonesia under Competitive Grant fiscal year 2017-2018.

\section{REFERENCES}

Awoyemi, L., Jones, I.P. 2011. Anatomical explanation for changes in properties of western red cedar (Thuja plicata) wood during heat treatment. Wood Science and Technology 45: 261-267.

Bao, F.C., Jiang, Z.H., Jiang, X.M., Lu, X.X., Luo, X.Q., Zhang, S.Y. 2001. Differences in wood properties between juvenile wood and mature wood in 10 species grown in China. Wood Science and Technology 35(4): 363-375.

Basri, E., Yuniarty, K. 2001. Research progress of mangium wood (Acacia mangium) in the Bogor Forest Products Research and Development Centre. A Discussion on Utilization Technology of Plantation Woods to Support Renewable Wood Industries. 7 November 2001. Bogor, Indonesia. BPS-Statistics Indonesia. 2015. Statistics of Forestry Production 2015. BPS-Statistics Indonesia, Jakarta, Indonesia.

Dong, Y., Yan, Y., Wang, K., Li, J., Zhang, S., Xia, C., Shi, S.Q., Cai, L. 2016. Improvement of water resistance, dimensional stability, and mechanical properties of poplar wood by rosin impregnation. European Journal of Wood and Wood Products 74(2): 177-184.

Esteves, B., Domingos, I., Pereira, H. 2008. Pine wood modification by heat treatment in air. Bioresources 3(1): 142-154.

Esteves, B., Marquez, A.V., Domingos, I., Pererira, H. 2007. Influence of steam heating on the properties of pine (Pinus pinaster) and eucalypt (Eucalyptus globulus). Wood Science and Technology 41: 193-207.

Esteves, B., Nunes, L., Domingos, I., Pereira, H. 2014. Improvement of termite resistance, dimensional stability and mechanical properties of pine wood by paraffin impregnation. European Journal of Wood and Wood Products 72(5): 609-615.

Esteves, B.M., Pereira, H.M. 2009. Heat treatment of wood. Bioresources 4(1): 370-404.

Fabiyi, J.S., Ogunleye, B.M. 2015. Mid-infrared spectroscopy and dynamic mechanical analysis of heat-treated obeche (Triplochiton scleroxylon) wood. Maderas Ciencia Y Tecnología 17(1): 5-16.

Gokhan, G., Denis, A. 2009. Some physical properties of heat-treated hornbeam (Carpinus betulus L.) wood. Drying Technology 27(5): 714-720.

Hao, Y., Pan, Y., Du, R., Wang, Y. 2018. The influence of a thermal treatment on the decay resistance of wood via FTIR analysis. Advance in Materials Science and Engineering 1: 1-7.

Hidayat, W., Qi, Y., Jang, J.H., Park, B.H., Banuwa, I.S., Febrianto, F., Kim, N.H. 2017. Color change and consumer preferences towards color of heat-treated Korean white pine and royal paulownia woods. Journal of the Korean Wood Science and Technology 45(2): 213-222.

Huang, X., Kocaefe, D., Kocaefe, Y., Pichette, A. 2018. Combined effect of acetylation and heat treatment on the physical, mechanical and biological behavior of jack pine (Pinus banksiana) wood. European Journal of Wood and Wood Products 76(2): 525-540.

Hung, N.M. 2016. Effect of temperature and time of dimensional stabilizing process on properties of 
shape transformed compressed wood. Forest Industry 5: 109-120.

Inayah, I. 2017. Physical, mechanical and finishing properties of silicon treated mindi wood (Melia azedarach Linn.). Undergraduate thesis. Institut Pertanian Bogor, Indonesia.

Kačíková, D., Kačík, F., Čabalová, I., Ďurkovi č, J. 2013. Effects of thermal treatment on chemical, mechanical and colour traits in Norway spruce wood. Bioresource Technology 144: 669-674.

Kamdem, D.P., Pizzi, A., Jermannaud, A. 2002. Durability of heat-treated wood. European Journal of Wood and Wood Products 60: 1-6.

Kang, C.W., Li, C., Jang, E.S., Jang, S.S., Kang, H.Y. 2018. Changes in sound absorption capability and air permeability of malas (Homalium foetidum) specimens after high temperature heat treatment. Journal of the Korean Wood Science and Technology 46(2): 149-154.

Karlinasari, L., Lestari, A.T., Priadi, T. 2018. Evaluation of surface roughness and wettability of heat-treated, fast-growing tropical wood species sengon (Paraserianthes falcataria (L.) I.C.Nielsen), jabon (Anthocephalus cadamba (Roxb.) Miq), and acacia (Acacia mangium Willd.). International Wood Products Journal 9(3): 142-148.

Kim, Y.K., Kwon, G.J., Kim, A.R., Lee, H.S., Purusatama, B., Lee, S.H., Kang, C.W., Kim, N.H. 2018. Effects of heat treatment on the characteristics of royal paulownia (Paulownia tomentosa (Thunb.) Steud.) wood grown in Korea. Journal of the Korean Wood Science and Technology 46(5): 511-526.

Kocaefe, D., Poncsak, S., Dore, G. 2008. Effect of heat treatment on wettability of white ash and soft maple by water. European Journal of Wood and Wood Products 66: 355-361.

Korkut, D.S., Korkut, S., Bekar, I., Budakç, M., Dilik, T., Cakıcier, N. 2008. The effects of heat treatment on the physical properties and surface roughness of Turkish hazel (Corylus colurna L.) wood. International Journal of Molecular Sciences 9: 1772-1783.

Krisnawati, H., Kallio, M., Kanninen, M. 2011a. Acacia mangium Wild: Ecology, Silviculture, and Productivity. Center for International Forestry Research (CIFOR), Bogor, Indonesia.

Krisnawati, H., Kallio, M., Kanninen, M. 2011 b. Anthocephalus cadamba Miq.: Ekologi, Silvikultur dan Produktivitas. Center for International Forestry Research (CIFOR), Bogor, Indonesia.

Lee, J.M., Lee, H.W. 2018. Dimensional stabilization through heat treatment of thermally compressed wood of Korean pine. Journal of the Korean Wood Science and Technology 46(5): 471-485.

Lim, H.M., Hong, S.H., Kang, H.Y. 2014. Investigation of the color change and physical properties of heat-treated Pinus koraiensis square lumbers. Journal of the Korean Wood Science and Technology 42(1): 13-19.

Mansur, I., Tuheteru, F.D. 2010. Jabon Wood. Penebar Swadaya, Jakarta, Indonesia.

Martawijaya, A., Kartasujana, I., Mandang, Y.I., Prawira, S.A., Kadir, I. 2005. Indonesian Wood Atlas II. Forestry Research and Development Agency, Bogor, Indonesia.

Nagarajappa, G.P., Pandey, K.K. 2016. UV resistance and dimensional stability of wood modified with isopropenyl acetate. Journal of Photochemistry \& Photobiology B: Biology 155: 20-27.

Park, Y., Eom, C., Han, Y., Park, J., Chang, Y., Yang, S., Choi, J., Yeo, H. 2014. Combined treatment of green pitch pine wood by heat and superheated steam and the effects on physical properties of the products. Holzforschung 68(3): 327-335.

Park, Y., Park, J.H., Yang, S.Y., Chung, H., Kim, H., Han, Y., Chang, Y.S., Kim, K., Yeo, H. 2016. Evaluation of physico-mechanical properties and durability of Larix kaempferi wood heat-treated by 
superheated steam. Journal of the Korean Wood Science and Technology 44(5): 776-784.

Park, Y., Han, Y., Park, J.H., Chung, H., Kim, H., Yang, S.Y., Chang, Y.S., Yeo, H. 2018. Evaluation of deterioration of Larix kaempferi wood heat-treated by superheated steam through field decay test for 12 months. Journal of the Korean Wood Science and Technology 46(5): 497-510.

Priadi, T., Hiziroglu, S. 2013. Characterization of heat treated wood species. Materials and Design 49: 575-582.

Rowell, R.M. 2006. Chemical modification of wood: A short review. Wood Material Science and Engineering 1(1): 29-33.

Todaro, L., Dichicco, P., Moretti, N., D’Auria, M. 2013. Effect of combined steam and heat treatments on extractives and lignin in sapwood and heartwood of Turkey oak (Quercus cerris L) wood. Bioresources 8(2): 1718-1730.

Vybohova, E., Kucerova, V., Andor, T., Balazova, Z., Velkova, V. 2018. The effect of heat treatment on the chemical composition of ash wood. BioResources 13(4): 8394-8408.

Widyorini, R., Khotimah, K., Prayitno, T.A. 2014. The effects of temperature and method of heating on the physical properties and finishing quality of mahagony wood. Jurnal Ilmu Kehutanan 8(2): 65-74.

Windeisen, E., Strobel, C., Wegener, G. 2007. Chemical changes during the production of thermo-treated beech wood. Wood Science and Technology 41: 523-536.

Won, K.R., Kim, T.H., Hwang, K.K., Chong, S.H., Hong, N.E., Byeon, H.E. 2012. Effect of heat treatment on the bending strength and hardness of wood. Journal of the Korean Wood Science and Technology 40(5): 303-310.

Won, K.R., Hong, N.E., Jung, S.Y., Kim, B.R., Byeon, H.S. 2017. Evaluation of two species of soft wood decay resistance for heat-treated wood using the catalyst $\left(\mathrm{H}_{2} \mathrm{SO}_{4}\right)$. Journal of the Korean Wood Science and Technology 45(2): 195201.

Xianjun, L., Zhiyong, C., Qunying, M., Yiqiang, W., Yuan, L. 2011. Effects of heat treatment on some physical properties of Douglas fir (Pseudotsuga menziesii) wood. Advanced Materials Research 197-198: 90-98. 